\title{
Development of Total Suspended Sediment Model using Landsat-8 OLI and In-situ Data at the Surabaya Coast, East Java, Indonesia
}

\author{
Teguh Hariyanto, Trismono C. Krisna, Khomsin, Cherie Bhekti Pribadi and Nadjadji \\ Anwar
}

Received: 0902 2016 / Accepted: 27062016 / Published online: 30062017

(C) 2017 Faculty of Geography UGM and The Indonesian Geographers Association

\begin{abstract}
The decrease of coastal-water quality in the Surabaya coastal region can be recognized from the conceentration of Total Suspended Sediment(TSS ). As a result we need a system for monitoring sediment concentration in the coastal region of Surabaya which regularly measures TSS. The principle to model and monitor TSSconcentration using remote sensing methods is by the integration of Landsat-8OLI satellites image processing using some ofTSS-models then those are analyzed for looking its suitability with TSS value direcly measured in the field (in-situ measurement). The TSS value modeled from all algorithms validated usingcorrelation analysis and linear regression. The result shows that TSS model with the highest correlation value is TSS algorithm by Budiman (2004)with $r$ value 0.991. Hence this algorithm can be used to investigate TSS-distribution which represent the coastal water quality of Surabaya with TSS value between $75 \mathrm{mg} / \mathrm{L}$ to $125 \mathrm{mg} / \mathrm{L}$.
\end{abstract}

Keywords: algorithm, coastal water, Landsat 8 OLI, Total Suspended Sediment (TSS), Surabaya

\begin{abstract}
Abstrak Penurunan kualitas perairan pantai dapat ditunjukkan oleh tingginya konsentrasi sedimen yang dinyatakan oleh Total Suspended Sedimen(TSS). Untuk keperluan ini diperlukan sistem monitoring dan pengukuran konsentrasi sedimen wilayah pantai Surabaya secara spasial dan non spasial, dimana pengukuran TSS dapat dilakukan secara regular dengan ketelitian yang baik. Prinsip monitoring konsentrasi TSS dengan metode penginderaan jauh adalah memproses citra dari satelit Landsat 8OLI dengan menggunakan beberapa model TSS, kemudian dilihat kesesuaiannya konsentrasi TSS yang diukur langsung di lapangan (pengukuran insitu).Penelitian ini menggunakan empat algoritma TSS untuk mendapatkan konsentrasi TSS. Nilai konsentrasi TSS dari semua algortima diuji dengan data in-situ menggunakan analisis regresi linier. Hasil menunjukkan bahwa algoritma Budiman mempunyai nilai korelasi yang paling tinggi(r=0,991).Algoritma tersebut dapat digunakan untuk melihat distribusi TSS yang merupakan indikator kualitas perairan pantai Surabaya dengan rentang nilai konsentrasi $75 \mathrm{mg} / \mathrm{l}$ sampai dengan $125 \mathrm{mg} / \mathrm{l}$.
\end{abstract}

Kata kunci: algoritma, Landsat 8 OLI, Total Suspended Sediment (TSS), perairan pantai, Surabaya

\section{Introduction}

Coastal areas often change in their function, the area which should be the conservation area or coastal protection, forests, as well as water catchment areas and mangrove forest habitat have been transformed into large scale residential area, industrial area, warehousing and others that have negative impacts on that region. Several cases of coastal reclamation area can be seen in coastal areas of Jakarta, as in the spatial plan of the city, the northern coastal region of Jakarta is designated as protected forest or mangrove forests, but in fact that region has been developed to be come residential area. As a result this triggers flooding in the wider regions. Form example,reclamation is a necessity for the development of the capital Jakarta, that aims to expand the area used for economic activities.

Likewise in the case of the Surabaya east coast region, the reclamation was influenced by several factors

Teguh Hariyanto, Trismono C. Krisna, Khomsin, Cherie Bhekti Pribadi and Nadjaji Anwar

Faculty of Civil Engineering and Planning, Institut Teknologi Sepuluh Nopember Surabaya.

Correspondent email: tgh_hary@yahoo.com. for instance the demand of residential areas, factories and so on, as well as due to the sedimentation in the river estuary which resulted in the emergence of 'new land'. The impact of the reclamation both technically (backfilling) or natural (newland) certainly have impacts either positively or negatively [Hariyanto,2014].

Monitoring the condition of the coast through TSS value change using Landsat-8 OLI (Operational Land Imager) satellite remote sensing in the Surabayaeast coast area is necessary since there are some important things to be noted as a result of the reclamation either technically or naturally (new land). The effects of the reclamation are coastline changes, social issues, population and others. Furthermore we need the update of TSS data which is necessary to determine operational policy and technical guidance for the government, public and private sector in the utilization of coastal region from occurring environmental changes

The utilization of TSS remote sensing models in the previous study was performed by Budiman [2004], Nurandani [2013] , Lestari [2009], and Rodriguez and Gilbes [2009]. Initial hypothesis is applied to obtain the highest correlation and best-fit linear regression equation 
of the TSS distribution to represent the condition of Surabaya coastal-water with 15 in-situ data sample.The TSS model which has correlation value close to 1 will be used as the basis for analyzing coastal water condition

The aims of this research are retrieveand evaluate TSS concentration distribution using four algorithms of TSS in Surabaya east coast from Landsat-8 OLI image. Evaluate TSS correlation result retrieved from four algorithms against in-situ data using correlation value ( $r$ ) and linier regression analysis. The best result will be used as the basis to explains the condition of Surabaya east coast

\section{The Methods}

Research location is in the East Coast of Surabayawhich has a center coordinate of $7^{\circ} 15^{\prime} 20^{\prime \prime}$ South and $112^{\circ} 49^{\prime} 50^{\prime \prime}$ East (Figure 1). The Sea region of Surabaya is divided into two zones, the first zone is the strait and located in the northern part while the second zone is the sea zones located in the eastern part. Both zones have different sea level characteristics caused by the ocean currents. Madura Strait is a narrow strait which connects the Java and Madura island. Java sea (southern part of Madura) in average has strong current which is $0.5 \mathrm{~m}$ and $0.6 \mathrm{~m} / \mathrm{s}$ at the surface and at the bottom of strait respectively. Tidal conditions on the north coast of Surabaya is SemiDiurnal with the highest tide (HHWS) and the lowest tide (LLWS) differences is $3.10 \mathrm{~m}$. Meanwhile, the sea level condition on the east coast of Surabaya has the characteristics of Semi Diurnal (two tide per day) with the highest tide (HHWS) and the lowest tide (LLWS)differences of $2.80 \mathrm{~m}$ with strong currents $0.4 \mathrm{~m} / \mathrm{s}$ on the surface and $0.48 \mathrm{~m} / \mathrm{s}$ at the bottom of the sea. Due to the sea level conditions in the eastern part of Surabaya, the occurrence of sedimentation is more likely compared to the northern part.

The spectral characteristics of Landsat 8 OLI is provided in Table 1. Landsat-8 OLI image used in this study was acquired on March 3, 2014 with the number of pat-119 and row- 065, the spatial resolution is $30 \mathrm{~m} \times 30 \mathrm{~m}$. Image-to-image registration is the matching of one image to another so the same geographic area is positioned coincident with respect to the other. This type of geometric correction is used when it is not necessary to have each pixel assigned a unique $\mathrm{x}, \mathrm{y}$ coordinate in a map projection [Baboo, 2011] (Figure 2) In order toget :

$$
\left(\begin{array}{l}
x \\
y
\end{array}\right)=T\left(\begin{array}{l}
u \\
v
\end{array}\right)(1)
$$

Every step involved in the imaging process has to be known, i.e., we need to know the inverse process of geometric transformation.

$$
\left(\begin{array}{l}
u \\
v
\end{array}\right)=T^{-1}\left(\begin{array}{l}
x \\
y
\end{array}\right)(2)
$$

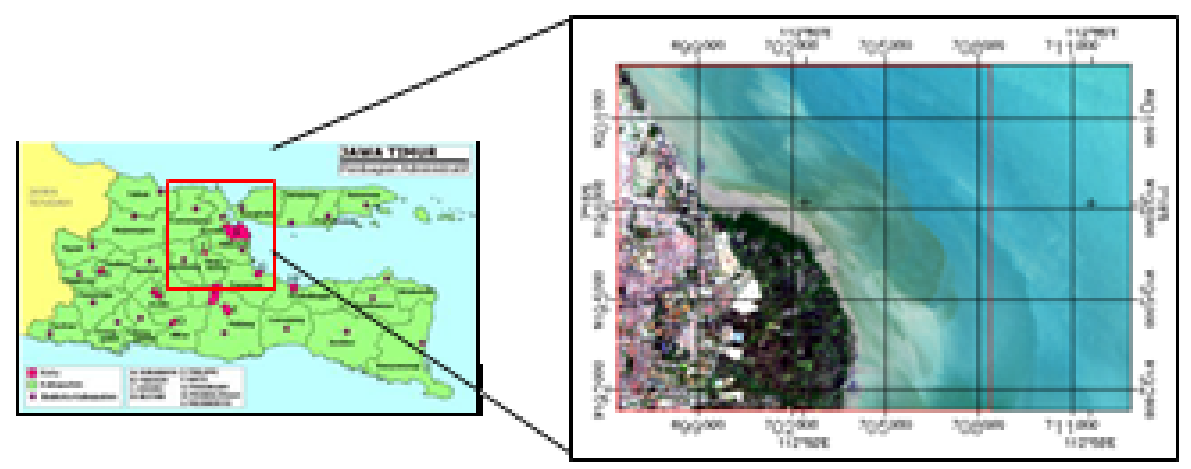

Figure 1. Research location, Surabaya east coast.

(Source: East Jawa Administration Map and Landsat 8 OLI)

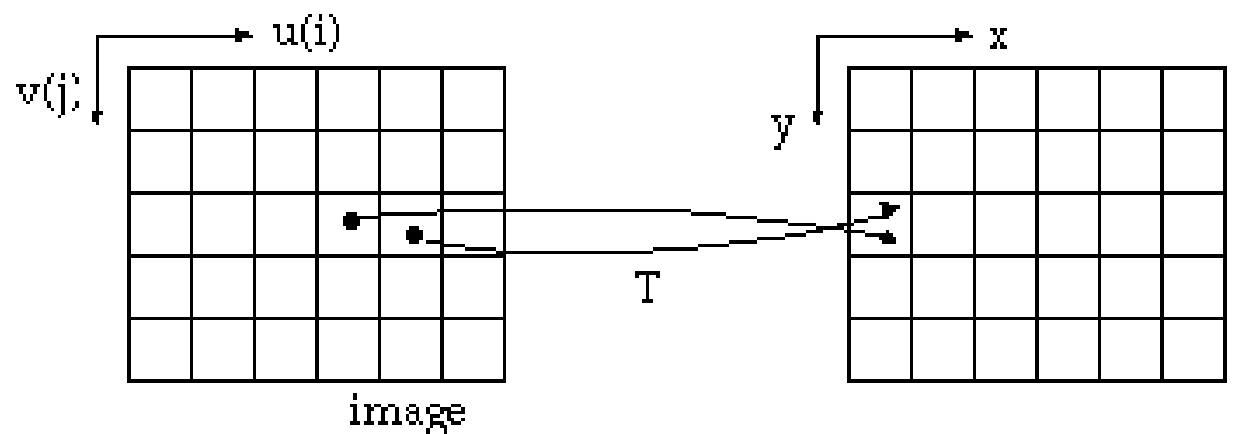

Figure 2. Image to image registration geometric correction.

(Source: http://nature.berkeley.edu/ penggong/textbook/chapter4/html/sect44.htm) 
Indonesian Journal of Geography, Vol. 49 No. 1, June 2017 : 73 - 79

\begin{tabular}{lcc}
\hline & Table 1. Landsat-8 (OLI) spectral band [Edgardh, 2013] \\
\hline Band & Wavelength $(\mu \mathrm{m})$ & Resolution $(\mathrm{m})$ \\
\hline B1-Visible (Aerosol) & $0.43-0.45$ & 30 \\
B2-Visible & $0.45-0.51$ & 30 \\
B3-Visible & $0.45-0.51$ & 30 \\
B4-NIR & $0.53-0.59$ & 30 \\
B5-NIR & $0.64-0.67$ & 30 \\
B6-SWIR1 & $0.85-0.88$ & 30 \\
B7-SWIR2 & $1.57-1.65$ & 30 \\
B8-PAN & $2.11-2.29$ & 15 \\
B9-Cirrus & $0.50-0.68$ & 30 \\
B10-TIRS1 & $1.36-1.38$ & 100 \\
B11-TIRS2 & 10.60 & 100 \\
& 11.19 & \\
\hline
\end{tabular}

This is a complex and time consuming process. However, there is a simpler and widely-used alternative, the polynomial approximation.

$$
\begin{aligned}
& u=\sum_{p=0}^{n} \sum_{q=0}^{n} a_{p q} x^{p} \cdot y^{q}(3) \\
& v=\sum_{p=0}^{n} \sum_{q=0}^{n} b_{p q} x^{p} \cdot y^{q}(4)
\end{aligned}
$$

Coefficients a's and b's are determined by using Ground Control Points (GCPs). For example, we can use very low order polynomials such as the affine transformation.

$$
\begin{gathered}
u=a x+b \Delta y+c(5) \\
v=d x+e \Delta y+f(6)
\end{gathered}
$$

A minimum of three GCPs will enable us to determine the coefficients in the above equations. Therefore, we did not need to use the transformation matrix T. However, in order to make our coefficients representative of the whole transformed image, we have to make sure that our GCPs are well distributed across the image [Camper, 2011]The distance between the input location of the GCP and the retransformed coordinates of the same GCP is called the Root Mean Square (RMS) error. This is calculated in the rectification formula as follows (see Table 2 for the result)

$$
\begin{aligned}
& R_{x}=\sqrt{\frac{1}{n} \sum_{i=1}^{n} X R_{i}^{2}}(7) \\
& R_{y}=\sqrt{\frac{1}{n} \sum_{i=1}^{n} Y R_{i}^{2}}(8)
\end{aligned}
$$

$T=\sqrt{R_{x}^{2}+R_{y}^{2}}$ or $R_{x}=\sqrt{\frac{1}{n} \sum_{i=1}^{n} X R_{i}^{2}+Y R_{i}^{2}}$

Where :

$$
\begin{array}{ll}
\mathrm{Rx} & =\mathrm{X} \text { RMS Error } \\
\mathrm{Ry} & =\text { Y RMS Error } \\
\mathrm{T} & =\text { Total RMS Error } \\
\mathrm{n} & =\text { the number of GCPs } \\
\mathrm{i} & =\text { GCP number } \\
\mathrm{XRi} & =\text { the X residual for GCPi } \\
\mathrm{YRi} & =\text { the Y residual for GCPi }
\end{array}
$$

\section{TSS in-situ Data.}

In-situ data came from water samples on the East Coast of Surabaya when were taken at March 24, 2014 by the random sampling method as much as 15 points in the study site at a depth of $0.5-2 \mathrm{~m}$.Furthermore water samples were processed using Gravimetry method in Water Laboratory of Environmental Engineering - ITS to obtain the value of TSS .

\section{Radiometric Correction}

Landsat 8 OLI band data can also be converted to Top-of-Atmospheric(TOA) planetary reflectance using reflectance rescaling coefficients provided in the product metadata file (MTL file). The following equation is used to convert $\mathrm{DN}$ values to TOA reflectance for Landsat 8 OLI data:

$$
\rho \lambda^{\prime}=M \rho Q c a l+A \rho(10)
$$

where:

$\rho \lambda^{\prime}=$ TOA planetary reflectance, with no correction 
Table 2. The result of geometric correction (pixel).

\begin{tabular}{llllllllll}
\hline GCP & Base X & Base Y & Warp X & Warp Y & Predict X & Predict Y & Error X & Error Y & RMS \\
\hline 1 & 3041.75 & 2366.25 & 2766.00 & 4845.50 & 2765.867 & 4845.580 & -0.1334 & 0.0796 & 0.155 \\
2 & 2662.50 & 2554.25 & 2385.75 & 5035.50 & 2385.758 & 5035.491 & 0.0082 & -0.0091 & 0.012 \\
3 & 2713.00 & 2330.00 & 2436.50 & 4810.25 & 2436.449 & 4810.284 & -0.0509 & 0.0337 & 0.061 \\
4 & 2664.24 & 2779.00 & 2367.50 & 5261.00 & 2367.440 & 5261.039 & -0.0603 & 0.0387 & 0.072 \\
5 & 3140.50 & 2813.50 & 2863.50 & 5295.25 & 2863.424 & 5295.296 & -0.0758 & 0.0457 & 0.089 \\
6 & 2943.50 & 2543.75 & 2666.75 & 5024.50 & 2667.060 & 5024.312 & 0.3096 & -0.1885 & 0.362 \\
7 & 3160.75 & 2536.75 & 2884.56 & 5016.77 & 2884.563 & 5016.770 & 0.0026 & -0.0001 & 0.003 \\
& & & \multicolumn{7}{c}{ RMS Error Total } \\
\hline
\end{tabular}

Table 3. TSS insitu laboratory data measured using Gravimetry method

\begin{tabular}{llll}
\hline No. Point & TSS $(\mathrm{mg} / \mathrm{L})$ & $\mathrm{X}(\mathrm{m})$ & $\mathrm{Y}(\mathrm{m})$ \\
\hline 1 & 44 & 704337 & 9193046 \\
2 & 29 & 702649 & 9200424 \\
3 & 62 & 704384 & 9195010 \\
4 & 29 & 704114 & 9199646 \\
5 & 94 & 703323 & 9196945 \\
6 & 36 & 703355 & 9198889 \\
7 & 30 & 705283 & 9198413 \\
8 & 34 & 699994 & 9200567 \\
9 & 47 & 701568 & 9199269 \\
10 & 40 & 701357 & 9201597 \\
11 & 24 & 706292 & 9192318 \\
12 & 28 & 706088 & 9194229 \\
13 & 35 & 699700 & 9202008 \\
14 & 76 & 706385 & 9195644 \\
15 & 60 & 706024 & 9197009 \\
\hline
\end{tabular}

for solar angle

$\mathrm{M} \rho=$ Band-specific multiplicative rescaling factor taken from the image metadata (REFLECTANCE MULT_BAND_x, where $\mathrm{x}$ is the band number) $A \rho=$ Band-specific additive rescaling factor taken from the image metadata (REFLECTANCE_ADD_ BAND_x, where $\mathrm{x}$ is the band number)

$\mathrm{Qcal}=\mathrm{DN}$

To obtainTOA reflectance value with a correction for the sun angle, the following formula was used

$$
\rho \lambda=\frac{\rho \lambda r}{\cos \left(\theta_{s z}\right)}=\frac{\rho \lambda r}{\sin \left(\theta_{s z}\right)}(11)
$$

where:

$\rho \lambda=$ TOA planetary reflectance

$\theta \mathrm{SE} \quad=$ Local sun elevation angle. The value of scene center sun elevation angle in degrees is provided in the metadata (SUN_ELEVATION)

$\theta \mathrm{SZ}=$ Local solar zenith angle; $\theta \mathrm{SZ}=90^{\circ}-\theta \mathrm{SE}$
Some models of TSS algorithm used in this study can be seen in the following explanation

\section{Result and discussion.}

Budhiman [2004] method is based on bio optical modeling. The forward water analysis comprised the laboratory measurements of water quality (TSS and Chlorophyll) and Inherent Optical Properties (IOPs) to derive Specific Inherent Optical properties (SIOPs). SIOPs of water (TSM, Chlorophyll and CDOM), coefficient $f$ and $B$ were used to developed $R(0-)$ model. The inverse atmosphere analysis encompassed several image pre-processing procedures (i.e geometric correction, atmospheric correction, air-water interface correction). The last step is the inverse water analysis, which comprised the development of algorithm and image processing to develop TSS concentration maps. The results indicate that red band of satellite sensor is sensitive to detect higher TSS concentration. Green band is sensitive to detect the lower TSS 
concentration. For Mahakam Delta, red band algorithm was used to derive TSS map, since higher TSS concentration occurred in the delta.The result can be seen in Figure 3 and the formula is as follow,

$$
\operatorname{TSS}(\mathrm{mg} / \mathrm{l})=7.9038 * \exp (23.942 * x)
$$

where :

$\mathrm{x}=$ reflextance of Band 3 (red)

TSS Algorithm 2 : Nurandani [2013]

Based on Nurandani [2013], who observed and measured TSS in Rawa Pening, the results of data processing, empirical matching algorithm for the concentration of TSS is a logarithmic regression equation model using the ratio between band 1 (blue) with band 2 (green) of Landsat 7 ETM+.Therefore it changes into band 2 (blue) and band 3 (green) on Landsat-8 OLI respectively. The equation is as follow: where :

$\mathrm{x}=$ Reflectance Ratio betwen band 2 and band 3

The majority of TSS value is between 75-100 $\mathrm{mg} / \mathrm{L}$, which covers almost all of the study area, while the value of TSS between $50-75 \mathrm{mg} / \mathrm{L}$ is distributed in Madura Strait.Using this algorithm , there is only limited area with TSS value between 25-50 mg/L.The TSS map can be seen in Figure 4.

\section{TSS algorithm 3: Lestari [2009]}

Based on Lestari [2009], the best empirical model to predict the concentration of TSS is the 3rd degree polynomial regression model, both for the dry and rainy seasons. The model is created by the relationship between the chromaticity transformation reflectance values of blue band with TSS concentration in-situ data. Here is the formula:

$\operatorname{TSS}(m g / l)=24197 x^{3}-22050 x^{2}+6813 x-644.98$
$\operatorname{TSS}(\mathrm{mg} / \mathrm{l})=368.7 * \ln (x)+31.52$

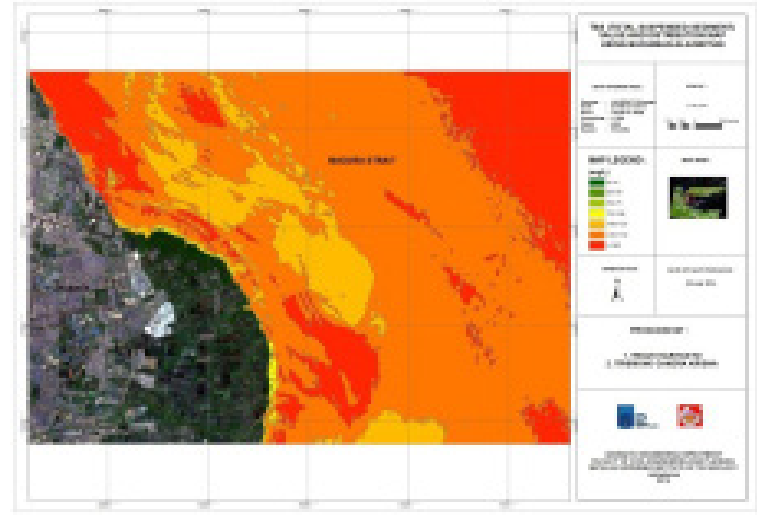

Figure 3. TSS map distribution using Budhiman [2004] algorithm.

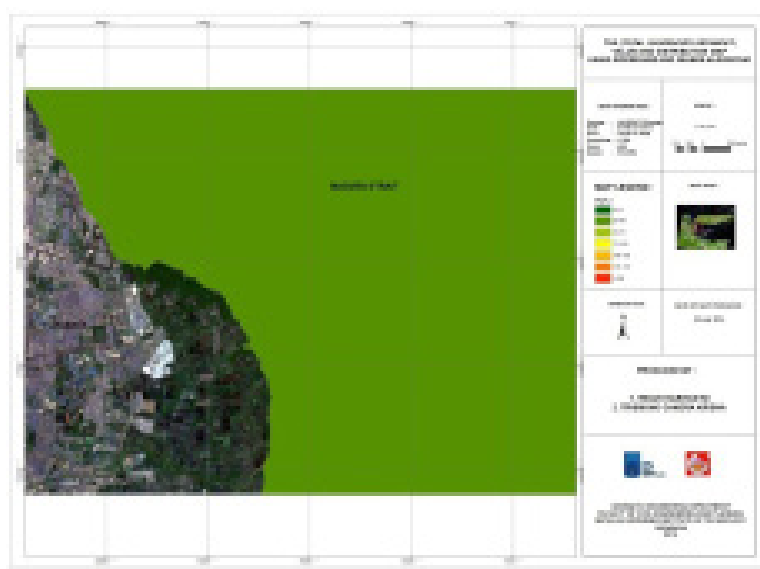

Figure 5. TSS distribution map using Lestari [2009] algorithm

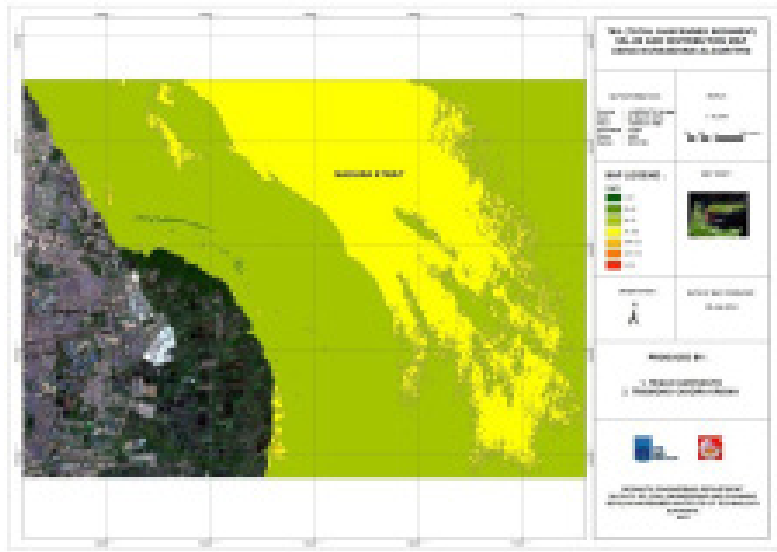

Figure 4. TSS map distribution using Nurandhani [2013] algorithm.

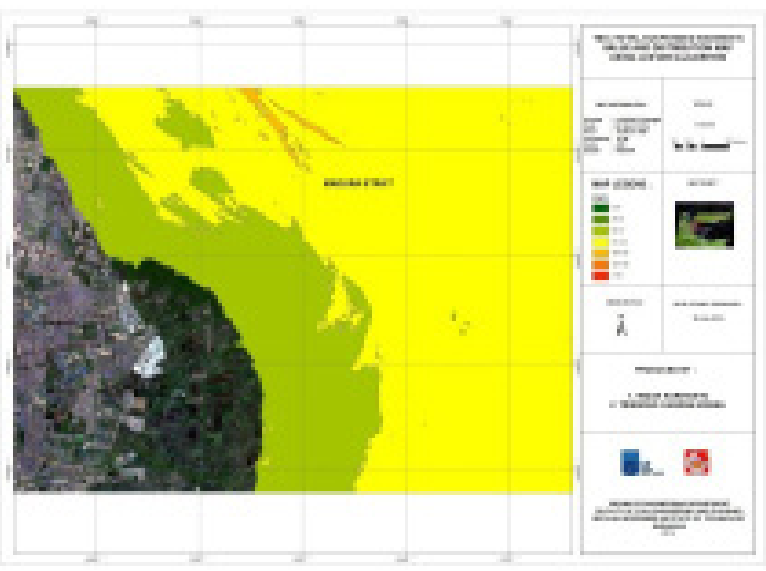

Figure 6. TSS distribusion map using Rodriguez and Gilbes [2009] algorithm 


\begin{tabular}{lllllll}
\hline \multicolumn{7}{c}{ Table 4. TSS and insitu data value } \\
\hline $\mathrm{X}$ & $\mathrm{Y}$ & Insitu & TSS 1 & TSS 2 & TSS 3 & TSS 4 \\
\hline 704337 & 9193046 & 44 & 134.5768 & 68.26647 & 37.70394 & 76.03919 \\
702649 & 9200424 & 29 & 123.707 & 56.95261 & 36.65344 & 63.01086 \\
704384 & 9195010 & 62 & 151.1878 & 69.24554 & 40.01199 & 77.60974 \\
704114 & 9199646 & 29 & 120.8465 & 56.90761 & 36.51542 & 62.26074 \\
703323 & 9196945 & 94 & 174.1747 & 72.03088 & 40.62543 & 79.58472 \\
703355 & 9198889 & 36 & 125.9703 & 65.10379 & 37.51991 & 73.6571 \\
705283 & 9198413 & 30 & 124.2871 & 61.22649 & 36.90648 & 66.31433 \\
699994 & 9200567 & 34 & 124.724 & 61.58656 & 37.31288 & 71.10242 \\
701568 & 9199269 & 47 & 139.628 & 68.74805 & 38.11801 & 76.21643 \\
701357 & 9201597 & 40 & 130.6984 & 67.49869 & 37.55825 & 74.63062 \\
706292 & 9192318 & 24 & 115.1877 & 55.3726 & 35.8253 & 60.07251 \\
706088 & 9194229 & 28 & 115.39 & 55.79576 & 35.83297 & 61.91773 \\
699700 & 9202008 & 35 & 125.6025 & 64.78537 & 37.45857 & 71.74793 \\
706385 & 9195644 & 76 & 161.5173 & 70.73078 & 40.28037 & 79.48254 \\
706024 & 9197009 & 60 & 143.8556 & 69.20729 & 38.83112 & 76.26843 \\
\hline
\end{tabular}

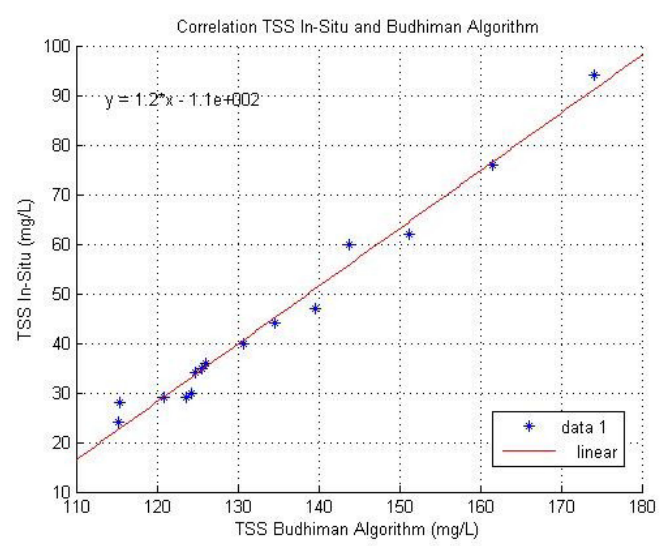

Figure 7. Linear regression analysis between TSS insitu over TSS retrieved using Budhiman [2004] algorithm.

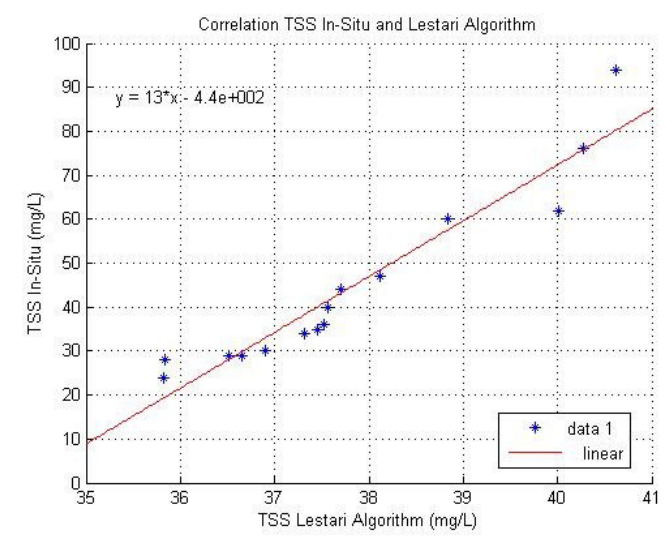

Figure 9. Linear regression between TSS insitu over TSS retrieved using Lestari [2009] algorithm.

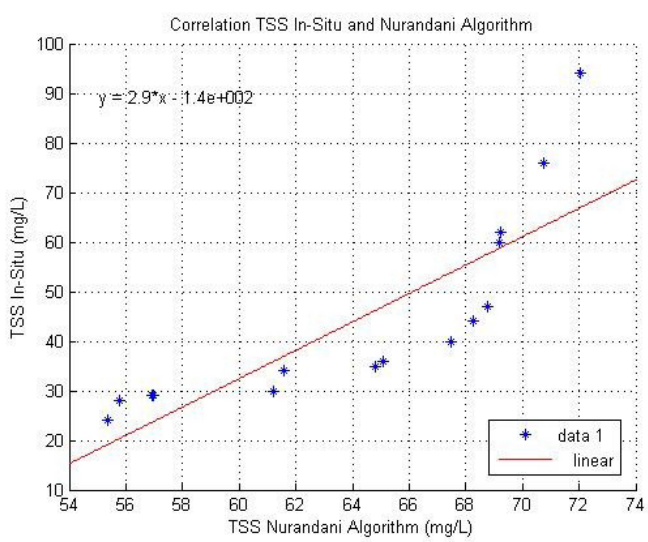

Figure 8. Linear regression between TSS insitu over TSS modeled using nurandani [2013] algorithm.

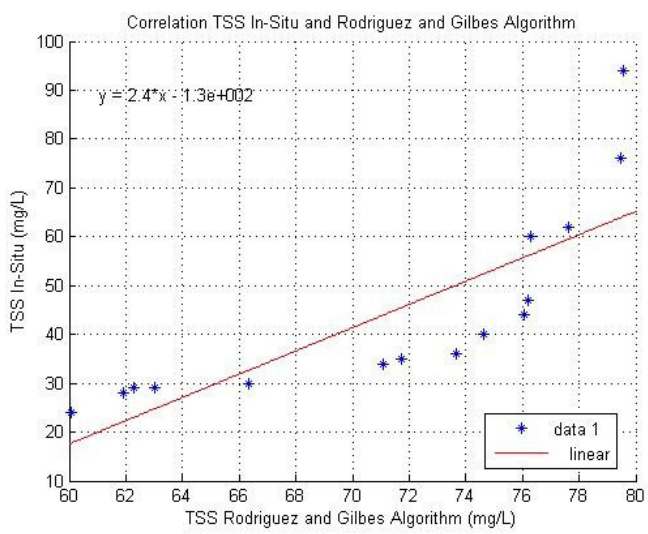

Figure 10. Linear regression between TSS insitu over TSS retrieved using Rodriguey and Gilbes [2009] algorithm. 
where :

$\mathrm{x}=$ reflectance of blue band 1 chromaticity. according to Wouthuyzen et al. (2008) in Lestari (2009), blue band chromaticity is : (band 2 / (band $2+$ band $3+$ band 4)

TSS distribution obtained usingLestarialgorithm can be seen in fig. 10 where the TSS value appears in the range of $25-50 \mathrm{mg} / \mathrm{L}$ TSS algorithm 4 : Rodriguez and Gilbes (2009). The result of Rodriguez and Gilbes (2009) algorithm shown in Figure 6 produced 3 broadest TSS value ranges.TSS range of $75-100 \mathrm{mg} / \mathrm{L}$ which covers the largest area, while the next largest TSS value is between $50-75 \mathrm{mg} / \mathrm{L}$ and the smallest area of TSS value is between $100-125 \mathrm{mg} / \mathrm{L}$.The formula is as follow :

$\mathrm{TSS}=602.63^{\star}\left(05157^{\star} \mathrm{x}-0.0089+3.1481\right.$

where :

$\mathrm{x}=$ reflectance band 2

Figure 7 explain the regression analysis between the TSS in-situ data over the TSS retrieved using Budhiman [2004] algorithm, where it has a good density at the sample number 3, 6 and 7 as well as at 8 and 9. Therefore, it has a high value of $\mathrm{R} 2=0.982$, while the correlation value $(r)$ is 0.991 . Figure 8 explains regression analysis between the TSS insitu data over TSS retrieved using Nurandani [2013] algorithm, where the highest density is at the sample number 11. From the calculation it has R2 of 0.684 and $r$ of 0.827 . Figure 9 explains the regression analysis between TSS insitu data with TSS modeled using Lestari [2009] algorithm, where good density appeared at sample number 3, 4, 10,11 and 13.The value of $\mathrm{R} 2$ is 0.915 while the value of $\mathrm{r}$ is 0.957 .

Figure 10 explains the regression analysis between the TSS in-situ data with TSS modeled using Rodriguez and Gilbes [2009] algorithm, where the relationship is quite poor R2 of 0.652 and $r$ of 0.807 . Based on analysis test for all TSS models using linear regression method, the maximum $r$ value was obtained from Budiman algorithm with $\mathrm{r}=0.991$. Hence the water condition in the eastern coast of Surabaya based on the results of Budiman's [2004] TSS algorithm has the biggest range of TSS value between $100-125 \mathrm{mg} / \mathrm{L}$. The value of $125 \mathrm{mg} / \mathrm{L}$ are located in the edge of the coastline indicating the new land formation as a result of the sedimentation process

\section{Conclusion}

The use of fourt TSS algorithms applied to Landsat- 8 OLI result in the TSS distribution vary from $40 \mathrm{mg} / \mathrm{L}$ up to $150 \mathrm{mg} / \mathrm{L}$, where the highest variety of TSS value was obtained using Budiman [2004] algorithm, whereas the lowest TSS value is obtained using Lestari [2009)] Nurandani [2013] and Rodriguez and Gilbes [2009] algorithms produced almost similar TSS valuesUsing four TSS algorithms above, model with the highest correlation with TSS Budhiman [2004] algorithm with $r$ value of 0.991 . The lowest correlation value was obtained from Rodriguez and Gilbes [2009] algorithm. The concentration of TSS in the east coast of Surabaya based on Budiman algorithm which has the largest value of $125 \mathrm{mg} / \mathrm{L}$, are distributed on the edge of the coastline, and thus increasing sedimentation process.

\section{References}

Baboo.S.S, (2011). Geometric Correction in Recent High Resolution Satellite Imagery : A Case Study in Coimbatore, International Journal of Computer Applications ,Volume 14- No.1, 0975 - 8887.

Budhiman, S, (2004). Mapping TSM Concentrations From Multi Sensor Satellite Images in Turbid Tropical Coastal Waters of Mahakam Delta Indonesia, Enschede: MSc Thesis ITC Enschede, The Netherlands.

Camper, (2011). Georeferencing (Geometric Correction), Remote Sensing and Image Analysis, University of California at Berkeley.

Edgardh.L.A, Landsat 8, LDCM Landsat data Continuity Mission NASA - USGS.

Hariyanto,T,(2014). Identification of TotalSuspendedSediment (TSS) Distribution at Surabaya East Coast Area in East Java Indonesia Using TSS Algorithm Implementation on Multi Temporal Satellite Images, International Journal of Earth Sciences and Engineering ISSN 09745904, Vol. 07, No. 04, August, 2014, pp. 1341-1346

Nurandani.P. (2013). Pemetaan Total Suspended Solid (TSS) Menggunakan Citra Satelit MultiTemporal di Danau Rawa Pening Provinsi Jawa Tengah. Teknik Geodesi Undip. Rodriguez-Guzman,V. And Gilbes .F.(2009). Using Modis $250 \mathrm{~m}$ Imagery to Estimate Total Suspended Sediment in a Tropical Open Bay. International Journal Of Systems Aplications Engineering \& Development 3(1):36-44. 